\title{
Production of Valuable Nanoparticles from Waste Protein Fibres
}

\author{
Fatemeh Dadashian ${ }^{1,2 *}$ and Niloofar Eslahi ${ }^{3}$ \\ ${ }^{1}$ Department of Textile Engineering, Amirkabir University of Technology, Iran \\ ${ }^{2}$ Center of Excellence on Functional Fibrous Structures and Environmental Enhancement, Amirkabir University of Technology, Iran \\ ${ }^{3}$ Department of Textile Engineering, Science and Research Branch, Islamic Azad University, Iran
}

Submission: September 25, 2017; Published: October 31, 2017

*Corresponding author: Fatemeh Dadashian, Department of Textile Engineering, Amirkabir University of Technology, Iran, Email: dadashia@aut.ac.ir

\begin{abstract}
Nowadays, recycling natural waste materials is the most appropriate way of dealing with the problems arising from disposal of large volumes of synthetic polymers in the environment. Among the natural materials, keratin proteins are potentially useful biopolymers for various applications from agriculture to biomedical. Keratin, which largely presents in poultry feather, wool, and hair, can be developed into various shapes and forms of foams, sponges, mats, films, gels, fibers, and powder. Since the protein powder could keep the original properties of the material without destroying the microstructure, it has been widely applied in modern industries. Nanoparticles can be produced by different methods such as milling, spray drying, electro spraying, rotary blades and sonication. The recovered keratin from natural resources in powder form has promising potential for a wide range of applications including cosmetics, filtration, composites, etc. This paper overviews a brief discussion on the subject.
\end{abstract}

Keywords: Protein; Natural fibers; Keratin; Nanoparticles; Enzyme

\section{Introduction}

Nanoscale materials have received attention owing to their high surface area to volume ratio and the unique chemical and physical properties. Recently, the research on the preparation of nanoparticles from natural polymers is given much importance [1]. Natural fibers, well known as environmental friendly materials, have the advantages of low density, low cost, and biodegradability. However, a considerable amount of these fibers has been wasted during industrial processes all over the world [2]. Protein wastes such as by-products from agricultural sources, wool textile industry, poor quality raw wool not fit for spinning, and hairs and feathers from butchery constitute an important renewable source of biopolymers [3]. Keratin is the major structural fibrous protein providing outer covering such as hair, wool, feathers, and nails with robust mechanical properties, thermal durability and resistance to physicochemical degradation. The intermolecular bonding of disulfide cystine amino acid and inter- and intra molecular bonding of polar and nonpolar amino acids in keratin results in its high stability and distinctive physical characteristics [4]. Wool is a natural fiber obtained from the fleece of sheep. This natural and multicellular staple fiber is mainly composed of proteins and organic substances [5]. Feathers are probably the most abundant protein material in nature. They represent from $5 \%$ to $7 \%$ of the body weight of chickens, being important by-products of the poultry industry, which are produced millions of tons annually throughout the world [6,7]. Recycling of these protein fibers in different forms such as films, gels, scaffolds, sponges and powders has been the objective of many studies due to their high protein content, biodegradability, and biocompatibility [8-10].

The protein powder could keep the original properties of the material without destroying the microstructure [11]. Many researchers have tried to produce particles by different methods such as regeneration from keratin solution, mechanical attrition and chemical-mechanical techniques [12-16]. Solution routes have inherent limitations in the preparation process, i.e. long time of dialysis, high production costs, safety and environmental constraints. Although mechanical attrition, which involves chopping and crushing the fibers with suitable milling machines can avoid these problems, it has high energy consumption [14]. Furthermore, this process is relatively difficult due to the softness and elasticity of the natural fibers leading to dispersity in particles shapes and size. Thus, special chemical pretreatments are usually employed to weaken the fibers structure and improve powder productivity [15]. The electro-spraying techniques can 
be also used to develop micro- and nanoparticles form natural polymers [16]. However, this process requires extraction of keratin solution from protein fibers at first. Several attempts have been made for the extraction of keratin using chemical, mechanical and enzymatic methods [17]. The presence of high cross-linking by disulfide bonds, hydrophobic interactions and hydrogen bonding in keratin makes it hard to extract [4].

The necessary step for keratin extraction is chemical deconstruction through targeted breaking of intermolecular disulfide bonds. This can be achieved by alkaline hydrolysis, reduction, oxidation, or sulfitolysis procedures [6]. Keratin hydrolyzed by alkaline hydrolysis was fragmented into small peptide fractions with low molecular mass having ease of solubility, while keratin from reduction hydrolysis provided higher molecular mass protein homologs with limited solubility but greater potential to form keratin products particularly for biomedical applications [18]. It should be also noted that the reductive or oxidative agents used for disulfide breakage, such as thiols or peroxides, are harmful, often toxic, and difficult to handle. On the other hand, enzymatic hydrolysis is the most attractive method from the environmental point of view, due to relatively mild treatment conditions and the preservation of functional properties of the hydrolysis products [3]. We have investigated production of nanoparticles from wool and feather fibers by enzymatic hydrolysis followed by ultrasonic treatment. The results indicated the positive effect of sonication on reducing particles size after enzymatic hydrolysis, while maintaining the basic chemistry and structural integrity of the native keratin protein [19-21].

\section{Conclusion}

Natural fibers are widely used materials in the textile industry because of their unique excellent properties. In recent years, there has been considerable interest in finding new applications of natural fibers based on regenerated protein through development of new products such as nanoparticles. Ultrafine powder can be prepared either by solution routes or by mechanical attrition of fibers. In the solution route, keratin should be extracted first by different chemicals and then particles from the aqueous solution are regenerated through a number of different methods such as spray drying. The mechanical method, on the other hand, avoids lengthy, costly and environmentally sensitive production procedures corresponding to the solution route. However, it requires special milling machines having high energy consumption. As a result, green and economical process has been attempted by researchers. For instance, we have shown that nanoparticles could be produced from waste protein fibers by enzymatic hydrolysis followed by ultrasonication, which is believed to be the most promising approaches because of the milder process conditions leaving no harmful by product. These protein nanoparticles have applications in various fields including cosmetics, coatings, filters, composites, dressings, tissue engineering, regenerative medicine and drug delivery, thanks to properties such as biocompatibility and biodegradability.

\section{References}

1. Sridhar R, Lakshminarayanan R, Madhaiyan K, Amutha Barathi V, Lim KH, et al. (2015) Electrosprayed nanoparticles and electrospun nanofibers based on natural materials: applications in tissue regeneration, drug delivery and pharmaceuticals. Chem Soc Rev 44(3): 790-814.

2. Fahim S, Elhaggar SM (2012) Reinforcement of plastic waste with treated natural fibers. Natural Resources 3(1): 6-10.

3. Eslahi N, Dadashian F, Nejad NH (2013) An investigation on keratin extraction from wool and feather waste by enzymatic hydrolysis. Prep Biochem Biotechnol 43(7): 624-648.

4. Sharma S, Gupta A (2016) Sustainable management of keratin waste biomass: applications and future perspectives. Brazilian Archives of Biology and Technology 59: e16150684.

5. Simpson W, Crawshaw G (2002) Wool: Science and Technology (1 $1^{\text {st }}$ edn), Wood head Publishing Ltd, Cambridge, USA.

6. Poole AJ, Church JS, Huson MG (2009) Environmentally sustainable fibers from regenerated protein. Biomacromolecules 10(1): 1-8.

7. Barone JR, Schmidt WF (2006) Effect of formic acid exposure on keratin fiber derived from poultry feather biomass. Bioresour Technol 97(2): 233-242.

8. Wrzesniewska-Tosik K, Wawro D, Steplewski W, Szadkowski K (2007) Fibrous products with keratin content. Fibres and Textiles in Eastern Europe 15(2): 30-35.

9. Vasconcelos A, Cavaco-Paulo A (2013) The use of keratin in biomedical applications. Curr Drug Targets 14(5): 612-619.

10. Wang J, Hao S, Luo T, Yang Q, Wang B (2016) Development of feather keratin nanoparticles and investigation of their hemostatic efficacy. Mater Sci Eng C Mater Bio Appl 68: 768-773.

11. Xu W, Wang X, Li W, Peng X, Liu X, et al. (2007) Characterization of Superfine Wool Powder/Poly(propylene) Blend film. Macromolecular Materials and Engineering 292(5): 674-680.

12. Cheng YF, Yuen CWM, Li Y, Ku SKA, Kan CW, et al. (2007) Characterization of nanoscale wool particles. Journal of Applied Polymer Science 104(2): 803-808.

13. Fujii T, Li D (2008) Preparation and properties of protein films and particles from chicken feather. J Biol Macromol 8(2): 48-55.

14. Rajkhowa R, Wang L, Wang X (2008) Ultra-fine silk powder preparation through rotary and ball milling. Powder Technology 185(1): 87-95.

15. Xu W, Cui W, Li W, Guo W (2004) Development and characterizations of super-fine wool powder. Powder Technology 140: 136-140.

16. Pedram Rad Z, Tavanai H, Moradi AR (2012) Production of feather keratin nanopowder through electrospraying. Journal of Aerosol Science 51: 49-56.

17. Fang Z, Zhang J, Liu B, Du G, Chen J (2013) Biodegradation of wool waste and keratinase production in scale-up fermenter with different strategies by Stenotrophomonas maltophilia BBE11-1. Bioresour Technol 140: 286-291.

18. Cardamone JM (2010) Investigating the microstructure of keratin extracted from wool: Peptide sequence (MALDI-TOF/TOF) and protein conformation (FTIR). Journal of Molecular Structure 969: 97-105.

19. Eslahi N, Dadashian F, Nejad NH (2013) Optimization of enzymatic hydrolysis of wool fibers for nanoparticles production using response surface methodology. Advanced Powder Technology 24(1): 416-426. 
20. Eslahi N, Dadashian F, Nejad Hemmatinejad (2014) From feather waste to valuable nanoparticles. Particulate Science and Technology 32(3): 242-250.
21. Eslahi N, Dadashian F, Hemmati Nejad N (2015) Method for synthesizing protein nanoparticles using waste chicken feathers US Patent 9: 695, 455.
This work is licensed under Creative Commons Attribution 4.0 Licens

DOI: 10.19080/CTFTTE.2017.01.555554

\section{Your next submission with Juniper Publishers} will reach you the below assets

- Quality Editorial service

- Swift Peer Review

- Reprints availability

- E-prints Service

- Manuscript Podcast for convenient understanding

- Global attainment for your research

- Manuscript accessibility in different formats

( Pdf, E-pub, Full Text, Audio)

- Unceasing customer service

Track the below URL for one-step submission https://juniperpublishers.com/online-submission.php 